\title{
PROBLEMS WITH RADIOMETRIC “TIME": DATING THE INITIAL HUMAN COLONIZATION OF SAHUL
}

\section{R. ESMÉE WEBB}

\author{
Yamaji Language Centre, P.O. Box 433, Geraldton, WA 6531 Australia
}

\begin{abstract}
Until recently, the only chronometric technique applied to Sahulian archaeological sites was ${ }^{14} \mathrm{C}$ dating; the ages obtained rarely exceeded $40,000 \mathrm{BP}$. Belief that the region was first colonized around that time has recently been shaken by luminescence dates from several archaeological sites in northern Australia that suggest people arrived between 60,000 and $55,000 \mathrm{BP}$. The ensuing debate over their validity revealed that some participants misunderstood luminescence dating and the temporal limitations of ${ }^{14} \mathrm{C}$ dating, illustrated here through a discussion of the tempo and mode of Sahulian colonization. Radiometric techniques cannot distinguish between the models proposed because they are unable to resolve temporal issues that occur within their limits of error.
\end{abstract}

\section{INTRODUCTION}

Sahul, the enlarged landmass shown in Figure 1, comprises New Guinea, Australia and Tasmania (White and O'Connell 1982). It existed during periods of eustatically lowered sea level. Island southeast Asia also formed an enlarged landmass during glacials, called Sundaland. Sahul has always been isolated from Sundaland by water barriers that form a major biogeographic divide, separating Sahulian marsupial faunas from Asian placental faunas (Wallace 1860). Even during glacial maxima, movement between Sundaland and Sahul by non-volant terrestrial animals entailed the successful passage of extensive stretches of open water. The only genera known to have crossed this barrier unaided are rodents, notoriously opportunistic colonists, and humans.

Determining when people first reached Sahul is important because it helps to establish when humans first displayed "modern" behavior (Davidson and Noble 1992). Sahulian colonization entailed establishing viable populations in diversely unfamiliar environments and the use of watercraft. Depending on when initial colonization occurred, it may also help to discriminate between the out-of-Africa and multiple-regional models for the evolution of anatomically modern humans (Kramer 1991; Thorne and Wolpoff 1992; Wilson and Cann 1992; Brown 1993). If Sahul was settled earlier than 100,000 BP, as recently claimed (Fullagar, Price and Head 1996), then the colonists could not have been anatomically modern humans, but must have derived from Homo erectus-like local populations. However, that date has yet to be confirmed. Discussion of the age of Jinmium, the site from which it came, must await the results of analyses currently being undertaken.

\section{DATING THE INITIAL HUMAN COLONIZATION OF SAHUL}

When Mulvaney (1969) published his first summary of Australian prehistory, few archaeological sites had been dated to $>10,000 \mathrm{BP}$. However, a mere six years later, so many new ${ }^{14} \mathrm{C}$ dates had become available that a revised version of his useful survey was issued in which the time of initial human arrival was pushed back to $c a .30,000$ BP (Mulvaney 1975). Further research permitted White and O'Connell (1982) to argue seven years later that Sahul was first colonized ca. 40,000 BP. Until very recently all subsequent research appeared to confirm that date, which has now become enshrined in the literature (Allen 1989; Bowdler 1989, 1993). Therefore, when concordant thermoluminescence (TL) and optically stimulated luminescence (OSL) dates from sites in Deaf Adder Gorge, Northern Territory, suggested that region was occupied by 60,000-55,000 BP (Roberts et al. 1994), they caused considerable controversy, because they are far older than the ages yielded by ${ }^{14} \mathrm{C}$ for Sahul as a whole. 


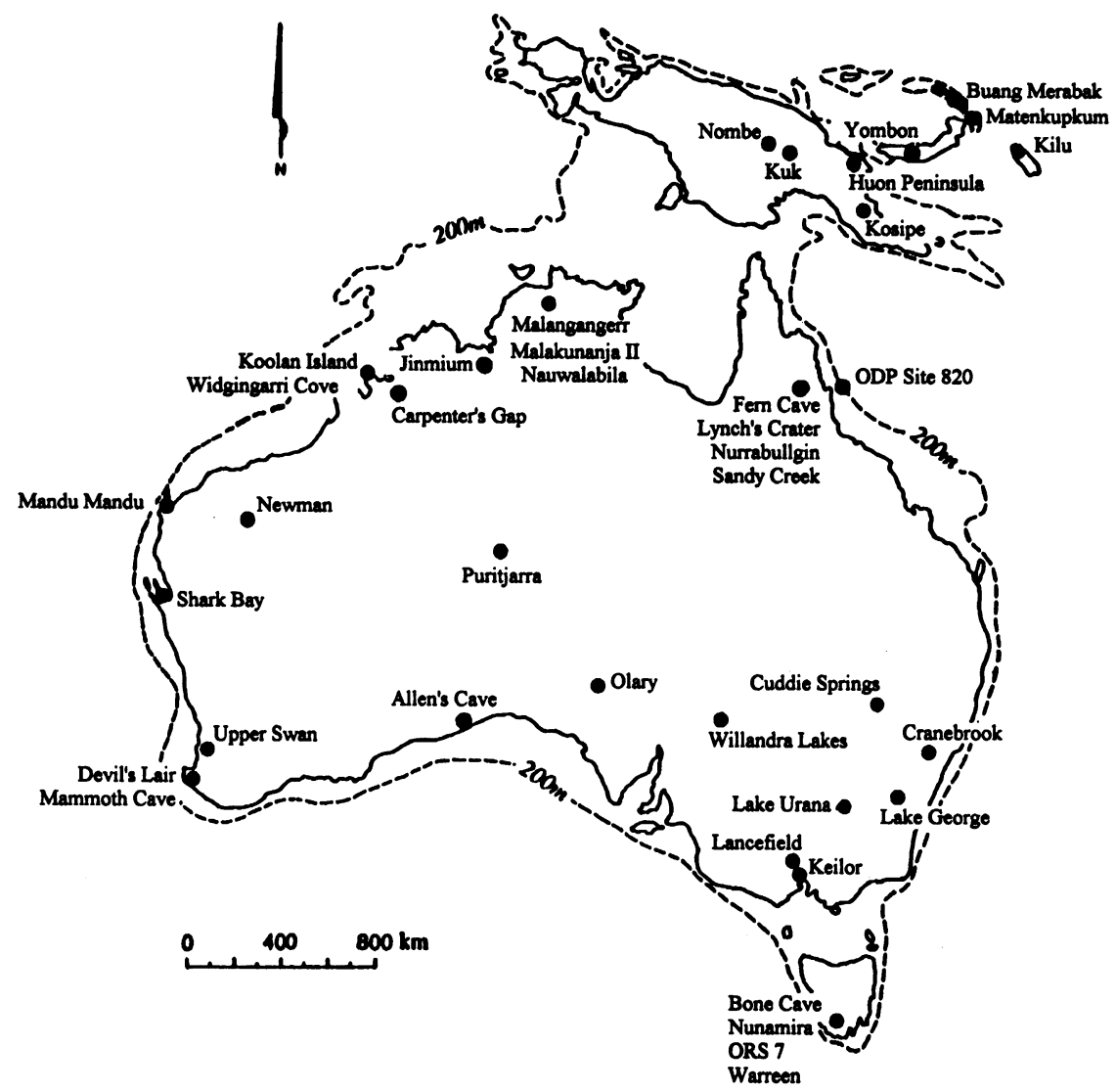

Fig. 1. Map showing the location of the oldest Sahulian sites

The antiquity of these luminescence dates not only revived discussion of when people first reached Sahul, but the ensuing debate revealed that some participants are confused about the temporal limitations of ${ }^{14} \mathrm{C}$ dating. The ${ }^{14} \mathrm{C}$ decay curve becomes asymptotic at $c a$. 35,000 BP (Chappell, Head and Magee 1996). Therefore, samples close to that age or older all tend to yield similar results, that do not necessarily reflect the true ages of the samples assayed. That few ${ }^{14} \mathrm{C}$ dates $>40,000 \mathrm{BP}$ are known from Sahulian archaeological sites is probably due to the harshness of the Australian environment, which ensures that organic material is rarely preserved in quantities suitable for dating in the oldest archaeological sites (Roberts, Jones and Smith 1994).

Allen and Holdaway (1995) attempted to disprove the luminescence dates and prove that Sahul was indeed first colonized after 40,000 BP by comparing ${ }^{14} \mathrm{C}$ dates from Australian archaeological sites with those from geological sites. They insisted that people arrived $c a .40,000 \mathrm{BP}$ because no archaeological sites dated to $>40,000 \mathrm{BP}$, whereas geological sites dated back to 55,000 BP (Fig. 2). However, the geological samples older than 40,000 BP discussed by Allen and Holdaway (1995) that I have been able to trace all came from Pulbeena and Mowbray, two peat swamps in Tasmania, and were dated by the Groningen laboratory. They were totally unlike those recovered from the oldest archaeological sites, which at best yield comminuted fragments of charcoal, shell or bone, usually from friable, unconsolidated sandy or silty deposits (Webb 1992) where the possibility of sample diagenesis is high. Such samples are inherently difficult to date. The Tasmanian samples, in contrast, 

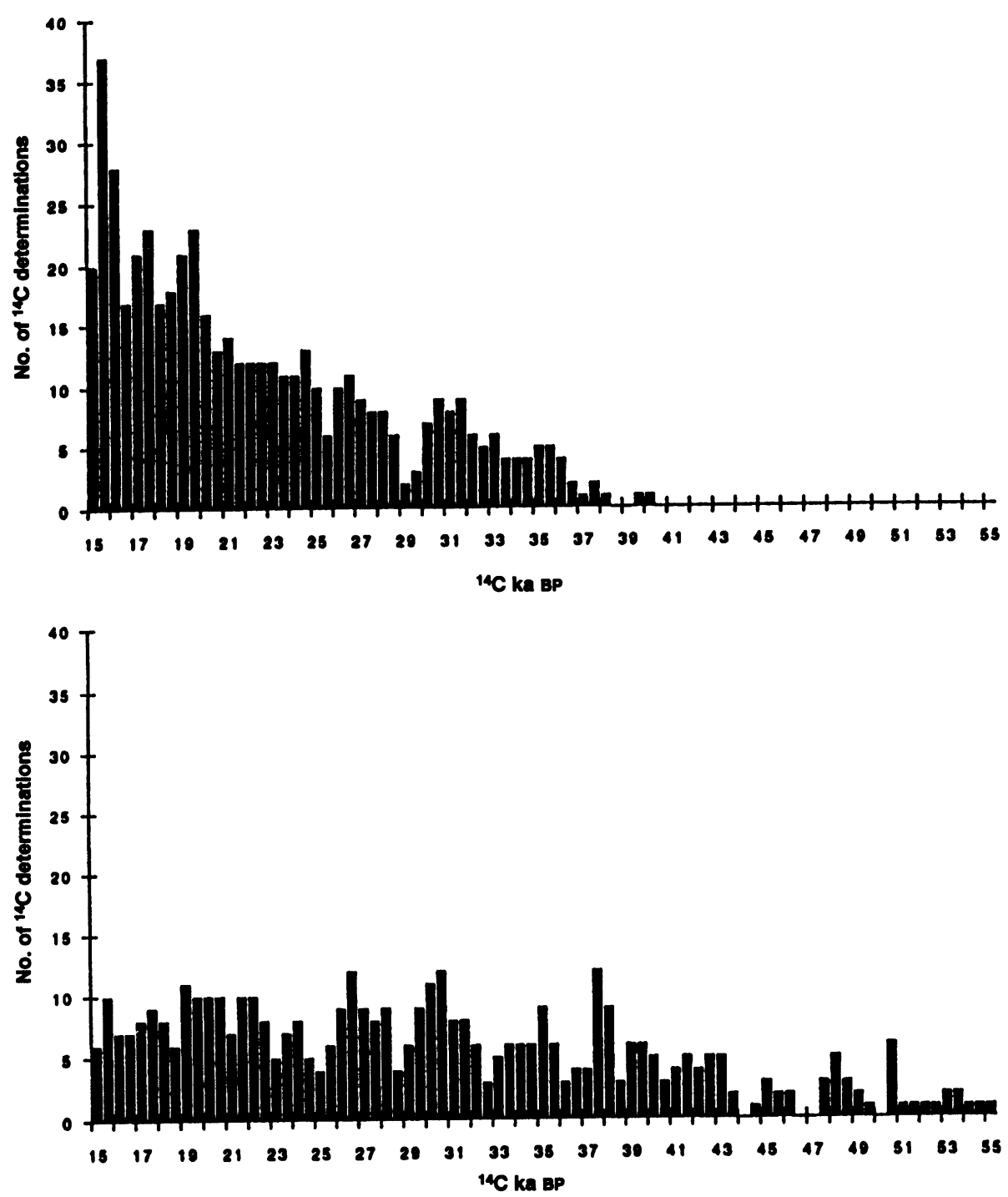

Fig. 2. Moving sums of archaeological (top) and geological (bottom) ${ }^{14} \mathrm{C}$ dates $>15,000 \mathrm{BP}$ from sites in Sahul (Allen and Holdaway 1995)

were ideal. They comprised root stumps from trees that grew around the swamps. Moreover, some of the dates were made using isotopic enrichment techniques that have never been applied to Australian archaeological samples, none of which were dated by Groningen. Hence, the data sets Allen and Holdaway (1995) compiled were not strictly speaking comparable; they comprised samples that differed greatly in quality and were dated using slightly different techniques.

In Figure 3, the Sahulian archaeological dates have been treated rather differently. Whereas Allen and Holdaway (1995) graphed all ${ }^{14} \mathrm{C}$ dates $>15,000 \mathrm{BP}$, I have included only the dates from the oldest deposits in the oldest archaeological sites. They have been culled from the archaeological literature, since few of the laboratories involved publish in Radiocarbon. Only five of these 130 dates 

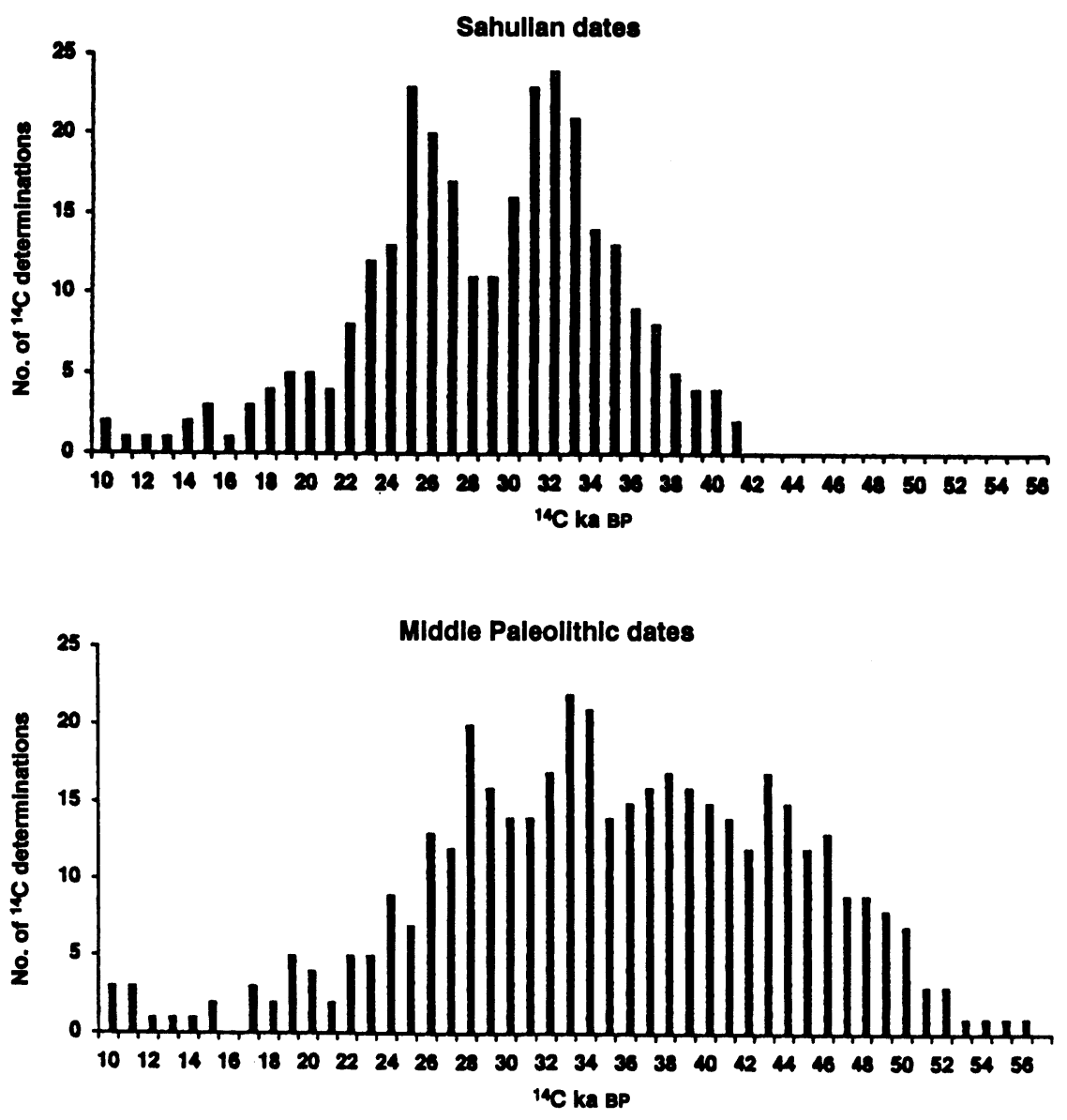

Fig. 3. Moving sums of the basal ${ }^{14} \mathrm{C}$ dates from the oldest archaeological sites in Sahul (top) and from Middle Paleolithic sites in Western Europe

were produced using AMS techniques; the others were all counted conventionally. They are compared with ${ }^{14} \mathrm{C}$ dates for the Western European Middle Paleolithic, culled from a database I have maintained for many years (Moffett and Webb 1983) that is updated regularly. They came originally from Radiocarbon, Archaeometry and date lists compiled by Eastern European researchers. Ten of the nearly 200 European dates are AMS. Most of the rest are conventional dates, but some were made on solid carbon.

Figure 3 shows that both data sets are Gaussian distributions, although their median ages differ by nearly 10,000 yr. While both include equally young ages, the Middle Paleolithic data set includes much older ages than the Sahulian data set. However, this does not mean that Allen and Holdaway's (1995) argument is correct. Of the nearly 50 Middle Paleolithic dates $>40,000$ BP that I have compiled, $>60 \%$ were produced by Groningen, sometimes using isotopic enrichment techniques. Moreover, $75 \%$ of the 30 finite dates were produced by Groningen, suggesting that this laboratory is particularly well equipped to date old samples precisely. On the other hand, despite their apparent precision, we know that many of these Middle Paleolithic ${ }^{14} \mathrm{C}$ dates are incorrect, because the sediments from which they came have also been dated geologically. They were deposited during the last 
interglacial or early part of the last glacial, 130,000-70,000 BP. Their antiquity has been confirmed by dates based on other radioisotopes, chiefly using TL and electron spin resonance (ESR), from other Middle Paleolithic sites in similar geological situations and the handful of sites in Figure 3 that have been redated using other isotopes. In most cases, these assays yielded older ages than ${ }^{14} \mathrm{C}$, although agreement between the TL and ESR dates is rare. A similar pattern has been observed at those few Sahulian sites with dates based on ${ }^{14} \mathrm{C}, \mathrm{TL}$ and/or OSL (Fig. 4). Hiscock (1990), Bowdler $(1990 \mathrm{a}, 1991)$ and Allen (1994) doubted the validity of the luminescence dates from these sites mainly because they diverge from the ${ }^{14} \mathrm{C}$ dates. They apparently did not realize that such disagreements are inevitable because ${ }^{14} \mathrm{C}$ and luminescence measure "time" on different materials that yield different ages (Frankel 1990).

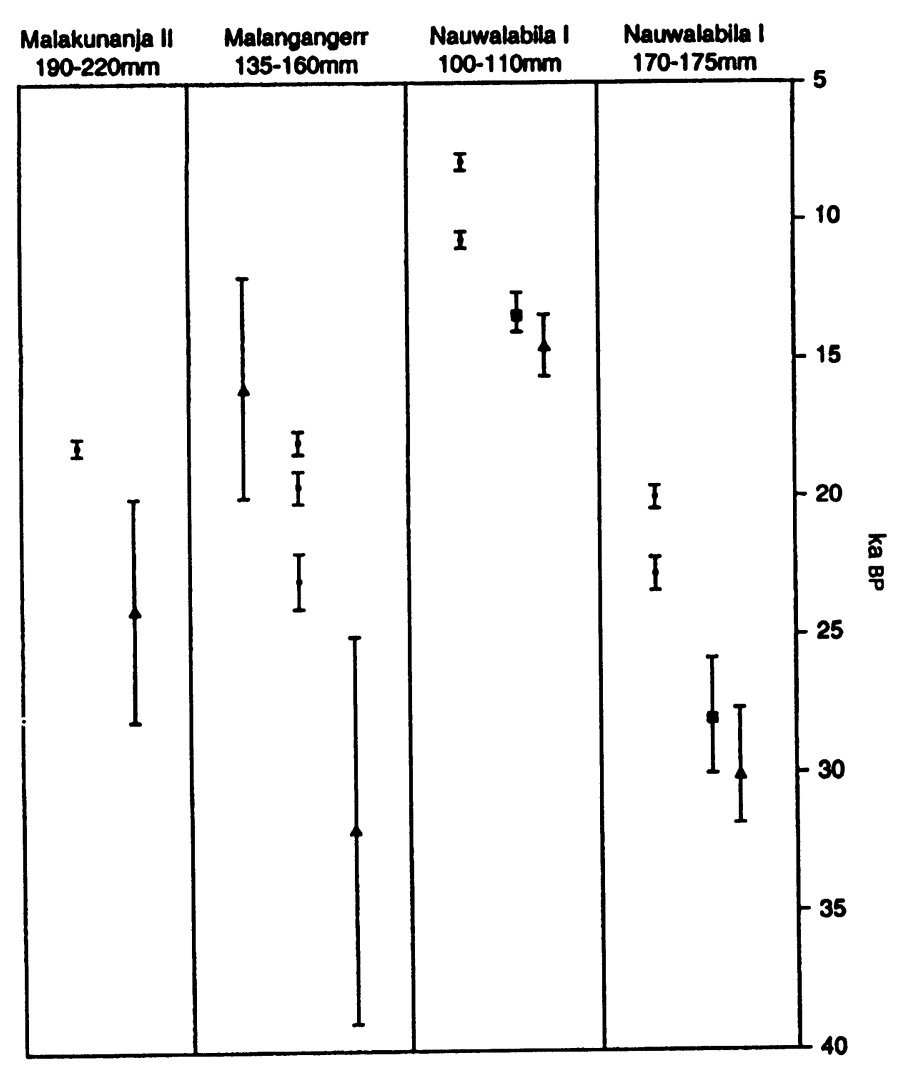

Fig. 4. Luminescence, both $\operatorname{TL}(\Delta)$ and $\operatorname{OSL}(\square)$, and ${ }^{14} \mathrm{C}(\bullet)$ dates from those levels in Arnhem Land sites where both techniques have been applied (Roberts et al. 1994)

Since we know that the temporal distribution of the Middle Paleolithic ${ }^{14} \mathrm{C}$ dates graphed in Figure 3 is misleading - many of the sites are older than their ${ }^{14} \mathrm{C}$ dates- there is no reason to suppose that the Sahulian dates reflect the true ages of the sites from which they came, either. Hence, the fact that few Sahulian sites have yielded ${ }^{14} \mathrm{C}$ dates $>40,000$ BP does not prove that humans did not reach the region earlier. Rather, it suggests that the samples submitted stretched conventional techniques to their limits. Moreover, the fact that the luminescence dates from the oldest archaeological horizons are much older than their ${ }^{14} \mathrm{C}$ dates does not mean the luminescence dates are necessarily invalid. 


\section{MODELING SAHULIAN COLONIZATION}

It would seem that in seeking to determine when Sahul was first colonized, the imprecision of dating techniques seriously limits the kinds of questions archaeologists can ask about that event. For example, the questions of how (mode) and how quickly (tempo) Sahul was settled have long been the focus of considerable debate. However, they cannot presently be answered because the available ${ }^{14} \mathrm{C}$ dates cannot discriminate between the conflicting explanations that have been proposed.

Birdsell (1977) argued that once people reached Australia, they would either have adapted rapidly to their new environment or not survived. Having no competitors, they would also have increased rapidly in numbers and spread to fill the entire continent within a few thousand years. Archaeologists such as Mulvaney $(1975)$, Allen $(1989)$ and Jones $(1989,1992)$ have also developed fast models of human colonization that support Birdsell's hypothesis. Other researchers, notably Bowdler (1977, 1990b), Horton (1981) and Lourandos (1987), considered Birdsell's estimate to be unrealistically short. They argued that gatherer-hunters from subtropical southeast Asia would have found adapting to Australia's mainly arid environment difficult. So they would have spread slowly.

Bowdler $(1977,1990 \mathrm{~b})$ maintains that the colonists must have been coastal people, or they would not have had the technology to cross the water barriers between Sundaland and Sahul. Hence, on reaching Australia they would initially have settled on the coast, an environment similar to their home territories. They might also have moved up major rivers, like the Murray-Darling, where they could have pursued familiar economies, but they would not have occupied the central deserts until all other niches were filled, during the Holocene. That part of her hypothesis has been negated by subsequent research. The "dead heart" of Australia was occupied before the last glacial maximum, if not earlier (Smith 1989; Smith, Prescott and Head 1997). Bowdler's "coastal colonization" model has also been widely criticized because none of the sites shown in Figure 1 was on the coast when it was initially occupied (Horton 1981; White and O'Connell 1982; Hallam 1987). They all lay well inland because eustatic lowering of the sea level had exposed the continental shelf, often for hundreds of kilometers offshore. The very earliest archaeological evidence for the human colonization of Sahul presumably lies on that shelf, underwater and unobtainable.

Rindos and Webb (1992) sought to resolve the colonization debate by presenting an alternative to both scenarios. We showed that rate of spread can be totally disconnected from rate of cultural change and/or adaptation to local conditions. We argued that people will spread rapidly through unfamiliar environments because they will be unable to exploit their resources efficiently. Hence, they will only be able to maintain low population densities, even in areas with intrinsically high carrying capacities, and will be forced to spread frequently, as their numbers increase. Conversely, we suggested that the better able people were to extract food from the environment in which they found themselves, the higher its carrying capacity for people would be and the more slowly their excess population would be forced to hive off. Hence, people will spread slowly through familiar environments to which they are well adapted. Therefore, if the initial Sahulian colonists had a well-developed coastal economy, their rate of spread should have been slow. Conversely, if their economies were poorly adapted to Sahulian conditions, their rate of spread should have been fast.

All three hypotheses can be tested by examining for signs of temporal patterning the ${ }^{14} \mathrm{C}$ ages from the basal archaeological layers in the oldest Sahulian sites. If colonization was slow, then sites in northern Sahul should clearly be older than those in Tasmania. Therefore, in Figure 5 the age ranges of the dated sites have been graphed with respect to latitude. Despite their apparent precision, the ages of sites such as Buang Merabak (31,990 \pm 830 BP: ANU-6614) or Puritjarra (21,950 $\pm 270 \mathrm{BP}$ : Beta-19901) are unlikely to have been determined reliably since they are based on single ${ }^{14} \mathrm{C}$ dates, 


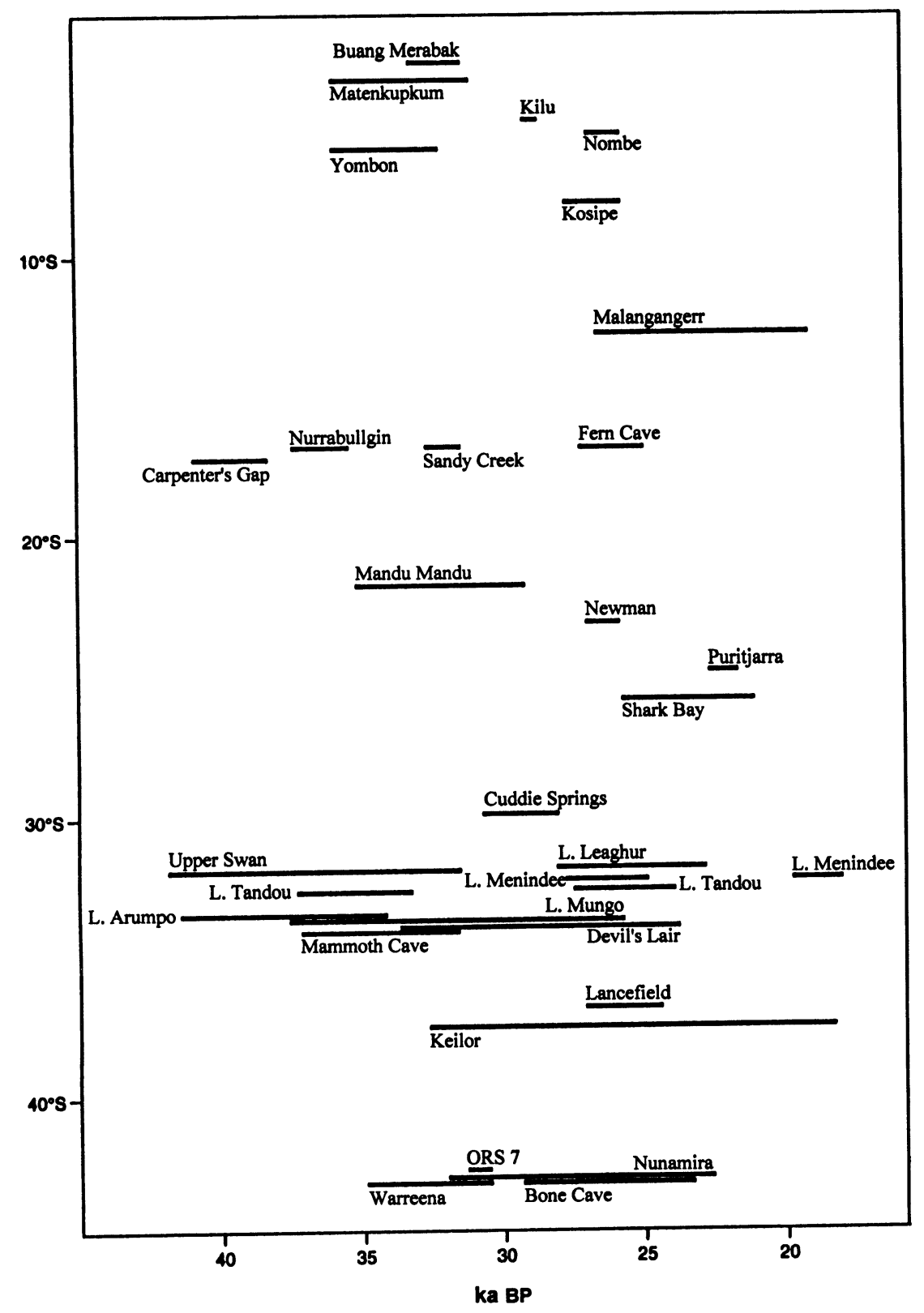

Fig. 5. Age ranges, graphed latitudinally, of those Sahulian sites with ${ }^{14} \mathrm{C}$ dates $>25,000 \mathrm{BP}$

which have been graphed as $1 \sigma$ time bars. The ages of sites such as Lake Mungo, part of the Willandra Lakes system (Fig. 1), where $17{ }^{14} \mathrm{C}$ dates are available from different areas, have been graphed as falling between the older end of the oldest and the younger end of the youngest $1 \sigma$ age ranges available (35,850 $\pm 2050 \mathrm{BP}$ : ANU-305 and 26,250 $\pm 1120 \mathrm{BP}$ : ANU-375b). The result spans a considerable period because a wide range of dates was obtained. Were ${ }^{14} \mathrm{C}$ dating able to discriminate between the times at which these sites were occupied, earlier sites would lie farther north. Instead, Figure 5 shows that the ages of sites all over Sahul overlap, suggesting that the region was occupied 
within the limits of error of the dates obtained. However, that does not mean that people spread rapidly (Webb and Rindos 1997, in press.).

The data on which Figure 5 is based are discussed in detail in Webb and Rindos (in press). We made no effort to discriminate between the dates available using the criteria devised by Waterbolk (1971) or Meltzer and Mead (1985) because our aim was to emphasize the temporal problems involved in dating Sahulian colonization. Moreover, application of their selection criteria to these dates would have proved difficult because insufficient information is available about the stratigraphic relationship between some of the samples submitted and the archaeological events they are supposed to date.

\section{PROBLEMS WITH RADIOMETRIC "TIME"}

Although the temporal imprecision inherent in all radiometric techniques limits the kinds of questions archaeologists can answer about the past, they often treat mean ages as if they were "true ages" in "real time". For example, Allen argued on the basis of ${ }^{14} \mathrm{C}$ dates of 37,000 BP from northern Queensland and 35,000 BP from southwestern Tasmania that Aborigines "spread through the diverse environmental zones of Australia in about 2000 years" and hence must have "adapted remarkably quickly" to the different environmental situations they encountered (Anderson 1991). Rindos and Webb (1992) would agree that humans are capable of adapting rapidly to new selective pressures, but we would dispute his conclusion because he ignored the error factors on the dates he discussed. At $1 \sigma$ the ranges of the dates on which he based his argument overlap. The two sites could have been occupied synchronously.

Australian archaeologists appear largely to have ignored the considerable literature on the statistics of comparing radiometric ages to determine whether the events they date were synchronous or diachronous (Long and Rippeteau 1974; Ward and Wilson 1978; Rick 1987; Buck et al. 1994; Buck, Litton and Scott 1994; Ward 1994). As these authors make clear, the range of each date must always be considered, not the mean age. The ANU ${ }^{14} \mathrm{C}$ dating manual advises that two ages can usually be presumed to date diachronic events if their age ranges at $1 \sigma$ are separated by an interval of time twice as great as the sum of their standard deviations, i.e., their mean ages are separated by three times the sum of their standard deviations. Webb and Rindos (1997, in press) call this period the "Radiometrically Instantaneous Interval" (RII) because it is impossible to determine whether events occurred synchronously or diachronously within its duration.

The RII concept can be illustrated by considering the following dates on charcoal from the Mungo I burial: 26,250 $\pm 1120 \mathrm{BP}$ (ANU-375b) and 31,100-1750 BP (ANU-1262). Most archaeologists would probably consider these dates diachronic because their mean ages are separated by nearly $5000 \mathrm{yr}$. However, because both dates have large standard deviations, their ranges overlap significantly at $3 \sigma:$ ANU-1262 $=37,850-25,850$ BP and ANU-375b $=29,610-22,890$ BP. Therefore, under the constraints of the RII concept, it is likely that they date a single event that occurred between 38,000 and $23,000 \mathrm{BP}$.

Obviously, the RII will vary in length dependent on the precision of the radiometric techniques employed and the ages being compared. Theoretically, it is possible to measure the age of ${ }^{14} \mathrm{C} \mathrm{sam}$ ples $40,000 \mathrm{yr}$ old to $\pm 1 \%=400 \mathrm{yr}$ (Gillespie 1991), although the variance on many conventional dates is far greater, particularly those produced some years ago. A standard deviation of $\pm 400 \mathrm{yr}$ would yield an RII value of $2500 \mathrm{yr}$. Such a long interval of temporal uncertainty has serious implications for determining the tempo of Sahulian colonization. The linear distance between the far north and southern Tasmania is $c a .4000 \mathrm{~km}$. The coastal distance is nearly twice as great. Thus, 
people could have spread at the slow rate of $2-3 \mathrm{~km}$ per year and still have reached Tasmania within $2500 \mathrm{yr}$, but such a rate of spread could not be measured radiometrically.

\section{CONCLUSION}

Webb and Rindos (1997, in press) concluded that it is impossible to discriminate between the fast and slow models of Sahulian colonization on the basis of the ${ }^{14} \mathrm{C}$ dates currently available. When the dates from individual sites are considered as $1 \sigma$ ranges they overlap, suggesting that the region was settled within the limits of error of the technique. Moreover, it can be argued that all radiometric dating techniques are inherently unable to resolve temporal issues that occur within the limits of error of the assays that date them. The current research project to obtain luminescence dates from as many as possible of the sites shown in Figure 1 may clarify whether people first reached Australia $>40,000$ BP. However, it will be unable to resolve the debate over the tempo and mode of that initial settlement, because luminescence dates are inherently less precise than ${ }^{14} \mathrm{C}$. Therefore, rather than continuing this sterile debate, Australian archaeologists are advised to seek either new data to aid its resolution, using AMS or high-precision techniques, or new problems to solve.

\section{ACKNOWLEDGMENTS}

I thank the organizers of the 16th Radiocarbon Conference for financial assistance that permitted me to attend the meeting in Groningen. This paper is abstracted from a much more detailed version written in conjunction with the late David Rindos and recently accepted by the Journal of Archaeological Science. I wish to acknowledge the debt I owe him for many of the ideas outlined above. Full details of all the radiometric dates from Sahul on which the argument advanced here is based can be found in our joint paper.

\section{REFERENCES}

Allen, J. 1989 When did humans first colonize Australia? Search 20: 149-154.

1994 Radiocarbon determinations, luminescence dating and Australian archaeology. Antiquity 68: 339 343.

Allen, J. and Holdaway, S. 1995 The contamination of Pleistocene radiocarbon determinations in Australia. Antiquity 69: 101-112.

Anderson, I. 1991 First Australians headed south in haste. New Scientist 132(1796): 3.

Birdsell, J. M. 1977 The recalibration of a paradigm for the first peopling of greater Australia. In Allen, J., Golson, J. and Jones, R., eds., Sunda and Sahul. London, Academic Press: 113-167.

Bowdler, S. 1977 The coastal colonisation of Australia. In Allen, J., Golson, J. and Jones, R., eds., Sunda and Sahul. London, Academic Press: 205-246. 1989 Australian colonization - a comment. Search 20: 173 .

1990a 50,000 year-old site in Australia - is it really that old? Australian Archaeology 31: 93.

1990b Peopling Australia: The "coastal colonisation" hypothesis re-examined. In Mellars, P. A., ed., The Emergence of Modern Humans. Edinbugh, Edinburgh University Press: 327-343.

1991 Some sort of dates at Malakunanja II: A reply to Roberts et al. Australian Archaeology 32: 50-51. 1993 Sunda and Sahul: A 30kyr BP culture area? In Smith, M. A., Spriggs, M. and Fankhauser, B., eds., Sahul in Review. Occasional Papers in Prehistory 24. Canberra, Prehistory Department, Research School of Pacific Studies, Australian National University: 6070.

Brown, P. 1993 Recent human evolution in East Asia and Australasia. In Aitken, M. J., Stringer, C. B. and Mellars, P. A., eds., The Origin of Modern Humans and the Impact of Chronometric Dating. Princeton, Princeton University Press: 217-233.

Buck, C. E., Christen, J. A., Kenworthy, J. B. and Litton, C. D. 1994 Estimating the duration of archaeological activity using ${ }^{14} \mathrm{C}$ determinations. Oxford Journal of Archaeology 13: 229-40.

Buck, C. E., Litton, C. D. and Scott, E. M. 1994 Making the most of radiocarbon dating: Some statistical considerations. Antiquity 68: 252-263.

Chappell, J., Head, M. J. and Magee, J. W. 1996 Beyond the radiocarbon limit in Australian archaeology and Quaternary research. Antiquity 70: 543-552.

Davidson, I. and Noble, W. 1992 Why the first colonisation of the Australian region is the earliest evidence of 
modern human behaviour. Archaeology in Oceania 27: 135-142.

Frankel, D. 1990 Time inflation. New Scientist 127 (1724): 52-53.

Fullagar, R. L. K., Price, D. M. and Head, L. M. 1996 Early human occupation of northern Australia: Archaeology and thermoluminescence dating of Jinmium rockshelter, Northern Territory. Antiquity 70: 751-773.

Gillespie, R. 1991 The Australian marine shell correction factor. In Gillespie, R., ed., Quaternary Dating Workshop 1990. Canberra, Department of Biogeography and Geomorphology, Australian National University: 15.

Hallam, S. J. 1987 Coastal does not equal littoral. Australian Archaeology 25: 10-29.

Hiscock, P. 1990 How old are the artefacts in Malakunanja II? Archaeology in Oceania 25: 122-124.

Horton, D. R. 1981 Water and woodland: The peopling of Australia. Australian Institute of Aboriginal Studies Newsletter 16: 21-27.

Jones, R. 1989 East of Wallace's line: Issues and problems in the colonisation of the Australian continent. In Mellars, P. A. and Stringer, C. B., eds., The Human Revolution. Edinburgh, Edinburgh University Press: 743-782.

1992 The human colonisation of the Australian continent. In Bräuer, G. and Smith, F. H., eds., Continuity or Replacement? Rotterdam, Balkema: 289-301.

Kramer, A. 1991 Modern human origins in Australasia: Replacement or evolution? American Journal of Physical Anthropology 86: 455-473.

Long, A. and Rippeteau, B. 1974 Testing contemporaneity and averaging radiocarbon dates. American Antiquity 39: 205-215.

Lourandos, H. J. 1987 Pleistocene Australia: Peopling a continent. In Soffer, O., ed., The Pleistocene Old World. New York, Plenum Press: 147-165.

Meltzer, D. J. and Mead, J. I. 1985 Dating late Pleistocene extinctions: Theoretical issues, analytical bias and substantive results. In Mead, J. I. and Meltzer, D. J., eds., Environments and Extinctions: Man in Late Glacial North America. Orono, Center for the Study of Early Man, University of Maine: 145-173.

Moffett, J. C. and Webb, R. E. 1983 Database management systems, radiocarbon and archaeology. In Stuiver, M. and Kra, R. S., eds., Proceedings of the 11th International ${ }^{14} \mathrm{C}$ Conference. Radiocarbon 25 (2): 667-668.

Mulvaney, D. J. 1969 The Prehistory of Australia. London, Thames and Hudson: $276 \mathrm{p}$.

1975 The Prehistory of Australia. 2nd. ed. Melbourne, Penguin: $327 \mathrm{p}$.

Rick, J. W. 1987 Dates as data: An examination of the Peruvian preceramic radiocarbon record. American An- tiquity 52: 55-73.

Rindos, D. J. and Webb, R. E. 1992 Modelling the initial human colonisation of Australia: Perfect adaptation, cultural variability and cultural change. Proceedings of the Australasian Society for Human Biology 5 : 441-454.

Roberts, R. G., Jones, R. and Smith, M. A. 1994 Beyond the radiocarbon barrier in Australian prehistory. Antiquity 68: 611-616.

Roberts, R. G., Jones, R., Spooner, N. A., Head, M. J., Murray, A. S. and Smith, M. A. 1994 The human colonisation of Australia: Optical dates of 53,000 and 60,000 years bracket human arrival at Deaf Adder Gorge, Northern Territory. Quaternary Science Reviews 13: 575-583.

Smith, M. A. 1989 The case for a resident human population in the Central Australian Ranges during full glacial aridity. Archaeology in Oceania 24: 93-105.

Smith, M. A., Prescott, J. R. and Head, M. J. 1997 Comparison of ${ }^{14} \mathrm{C}$ and luminescence chronologies at $\mathrm{Pu}$ ritjarra rockshelter, Central Australia. Quaternary Science Reviews 16: 299-320.

Thorne, A. G. and Wolpoff, M. H. 1992 The multiregional evolution of humans. Scientific American 266(4): 28-33.

Wallace, A. R. 1860 On the zoological geography of the Malay Archipelago. Zoological Journal of the Linnean Society of London 4: 172-184.

Ward, G. K. 1994 On the use of radiometric determinations to "date" archaeological events. Australian Aboriginal Studies 1994/2: 106-109.

Ward, G. K. and Wilson, S. R. 1978 Procedures for comparing and combining radiocarbon age determinations: A critique. Archaeometry 20: 19-32.

Waterbolk, H. T. 1971 Working with radiocarbon dates. Proceedings of the Prehistoric Society 37(2): 15-33.

Webb, R. E. 1992 Sand traps for the unwary - problems in the interpretation of sedimentological analyses. Queensland Archaeological Research 9: 43-9.

Webb, R. E. and Rindos, D. J. 1997 The mode and tempo of the initial human colonisation of empty landmasses: Sahul and the Americas compared. In Clark, G. A. and Barton, M., eds., Rediscovering Darwin: Evolutionary Theory in Archaeological Explanation. Washington, D.C., American Anthropological Society: 233-250.

, in press, When "fast" was "slow": the initial human colonisation of Sahul was radiometrically "instantaneous". Journal of Archaeological Science.

White, J. P. and O'Connell, J. F. 1982 A Prehistory of Australia, New Guinea and Sahul. Sydney, Academic Press: 286 p.

Wilson, A. C. and Cann, R. L. 1992 The recent African genesis of humans. Scientific American 266(4): 2227. 